\title{
Anti-Tumor and Anti-Inflammatory Activity In Vivo of Apodanthera congestiflora Cogn. (Cucurbitaceae)
}

\author{
Geovana F. G. Silvestre ${ }^{1}{ }^{\mathbb{D}}$, Renally P. Lucena ${ }^{2}$, Genil D. Oliveira ${ }^{2}$, Helimarcos N. Pereira ${ }^{3}$, Jhonatta A. B. Dias ${ }^{3}$, \\ Ivone A. Souza ${ }^{3}$ and Harley S. Alves ${ }^{1,2, *}$ \\ 1 Post-graduation Program of Pharmaceuticals Sciences, State University of Paraíba, \\ Campina Grande 58429-500, Brazil; geovana.silvestre@aluno.uepb.edu.br \\ 2 Department of Pharmacy, State University of Paraíba, Campina Grande 58429-500, Brazil; \\ renally.lucena@aluno.uepb.edu.br (R.P.L.); genil.oliveira@aluno.uepb.edu.br (G.D.O.) \\ 3 Department of Antibiotics, Federal University of Pernambuco, Recife 50670-901, Brazil; \\ helimarcosnunes@servidor.uepb.edu.br (H.N.P.); jhonatta.dias@ufpe.br (J.A.B.D.); \\ ivone.souza@ufpe.br (I.A.S.) \\ * Correspondence: harley@servidor.uepb.edu.br; Tel.: +55-83-3315-3353
}

Citation: Silvestre, G.F.G.; Lucena, R.P.; Oliveira, G.D.; Pereira, H.N.;

Dias, J.A.B.; Souza, I.A.; Alves, H.S. Anti-Tumor and Anti-Inflammatory Activity In Vivo of Apodanthera congestiflora Cogn. (Cucurbitaceae). Pharmaceutics 2021, 13, 743. https:// doi.org/10.3390/pharmaceutics13050743

Academic Editor: Anna Rita Bilia

Received: 18 April 2021

Accepted: 14 May 2021

Published: 18 May 2021

Publisher's Note: MDPI stays neutral with regard to jurisdictional claims in published maps and institutional affiliations.

Copyright: (c) 2021 by the authors. Licensee MDPI, Basel, Switzerland. This article is an open access article distributed under the terms and conditions of the Creative Commons Attribution (CC BY) license (https:// creativecommons.org/licenses/by/ $4.0 /)$.

\begin{abstract}
This work aimed to carry out a study of Apodanthera congestiflora by investigating its chemical composition and pharmacological potential. From the dichloromethane phase (Dic-Ac) of the $A$. congestiflora stems, three compounds were identified: cayaponoside $C_{5 b}$ (Ac-1), cabenoside $C$ (Ac-2) and fevicordin $\mathrm{C}_{2}$ glucoside (Ac-3), being last identified for the first time as a natural product. These compounds were obtained by chromatographic methods and their structures were elucidated by means of spectroscopic analysis of IR, MS and NMR. In the quantification of Dic-Ac, it was possible to observe the presence of $7 \%$ of cayaponoside $C_{5 b}$. Dic-Ac showed significant toxicity for in vivo tests, with macroscopic and biochemical changes. The anti-inflammatory activity of Dic-Ac was investigated using the paw edema model. A decrease in inflammatory signs was observed in the first $5 \mathrm{~h}$ and the most effective dose in reducing edema with was $7.5 \mathrm{mg} \mathrm{kg}^{-1}$ (66.6\%). Anti-tumor activity of Dic-Ac was evaluated by Ehrlich's carcinoma model, which showed inhibition rate of $78.46 \%$ at $15 \mathrm{mg} \mathrm{kg}^{-1}$ dosage. The phytochemical investigation, together with the biological tests carried out in this study, demonstrated that $A$. congestiflora is a promising species in the search for therapeutics, since it contains substances with high pharmacological potential in its composition.
\end{abstract}

Keywords: Cucurbitaceae; norcucurbitacins; acute toxicity; anti-inflammatory; Ehrlich's carcinoma

\section{Introduction}

With worldwide distribution and a high number of species, the family Cucurbitaceae Juss. is considered one of the most important families in the world of flora [1]. In Brazil, 30 genera and 160 species are registered and distributed in all regions of the country [2]. According to Silva et al. (2016) [3], cucurbits have considerable economic importance, due to the consumption of their vegetables that are produced and valued by the population, as is the case of the variant species of melon (Cucumis melo L.), watermelon (Citrullus lanatus (Thunb Matsum \& Nakai)) and pumpkins (Cucurbita sp.).

In addition to the nutritional use of its fruits, ethnobotanical records point to the use of several species of the Cucurbitaceae family in popular medicine, as well as showing the presence of compounds with a broad biological spectrum, such as cucurbitacins. This group of secondary metabolites has great chemical and biological relevance, as it presents a vast structural diversity and pharmacological potential. The anti-inflammatory, antidiabetic, antiulcerogenic, analgesic, antiparasitic and antitumor properties can be cited $[4,5]$.

Although cucurbitacins have a wide biopharmaceutical spectrum, most investigations involve anti-tumor activity [6]. The pioneering studies that relate cucurbitacins to an anti-tumor potential date from the 1960s, which made the class known for presenting this 
property. This fact can support the use of plants that contain them for various purposes that involve, directly or indirectly, cell death [4,5]. According to Ali et al. (2019) [7], cucurbitacins was able to treat cancers such as human lung adenocarcinoma, glioblastoma multiform, nasopharyngeal carcinoma, or chronic lymphocytic leukemia. The anti-inflammatory activity was mentioned by Ríos, Escandell and Recio (2005) [8] and Kaushik et al. (2015) [9], who pointed out that these substances can act in different signaling pathways of the immune system.

Madaleno (2011) [10] and Roque and Loiola (2013) [11] observed that in the Caatinga of Northeast Brazil, the species Apodanthera congestiflora is one of the Cucurbits most cited in studies of species for medicinal purposes. Named by Martínez Crovetto in 1954 as Melothria congestiflora Mart. Crov., A. congestiflora is a woody vine endemic to Brazil. Popularly known as "teiú" and "cabeça-de-nego", it is used in popular medicine mainly in the form of tea/licking to relieve pain in the spine and as a blood purifier ("thick blood"). The tea prepared with the roots is also indicated for external use to treat skin blemishes and itchiness [12].

Even though the species A. congestiflora is mentioned in the literature as a medicinal plant, the absence of studies related to the species is a factor that motivates chemicalpharmacological research focusing on the discovery of therapeutic agents and the development of new drugs. So far, reports about this species are scarce and refer only to the roots $[13,14]$. The objective of this research was to conduct a chemical-pharmacological study of the A. congestiflora stems, promoting the identification of chemical compounds as well as assessing the safety of use, anti-tumor and anti-inflammatory activity of extracts derived from the species.

\section{Materials and Methods}

\subsection{Plant Material}

The stems from $A$. congestiflora were collected from adult plants in the municipality of Barra de Santana, in the Paraíba semi-arid region $\left(6^{\circ} 43^{\prime} 18^{\prime \prime}\right.$ S- $36^{\circ} 03^{\prime} 46^{\prime \prime}$ W), which were subjected to selection, cutting and cleaning processes, with branches containing reproductive parts of the plant being reserved for the making and storage of exsiccate in the herbarium Manuel de Arruda Câmara-number 1000 of the State University of Paraíba, Campina Grande-PB. The drying was carried out in an oven with renewal and air circulation, at a temperature of $40^{\circ} \mathrm{C}$, until moisture stabilization was reached. After drying, the material was pulverized in a knife mill, with a defined granulometry of around 10 mesh. Then, the plant drug was packaged in a hermetically sealed bottle, protected from air and solar radiation.

\subsection{Extaction and Liquid: Liquid Partition}

The plant material $(1.5 \mathrm{~kg})$ was subjected to extraction by maceration with an ethanol solution at $70 \%$. Twelve extractions were performed using $5 \mathrm{~L}$ of solvent at each change, within an interval of $72 \mathrm{~h}$. The obtained macerate went through a process of alcohol evaporation, under reduced pressure, in a rotary evaporator TE-211 (Tecnal ${ }^{\circledR}$, Piracicaba, SP, Brazil) at a temperature of $50^{\circ} \mathrm{C}$. Then, the extractive solution was subjected to drying in a lyophilizer model LS3000 (Terroni, São Carlos, SP, Brazil) providing $233 \mathrm{~g}(15.53 \%)$ of hydroethanolic extract (HE-Ac).

Part of the HE-Ac (200 g) was solubilized in a methanol:water solution (7:3-v:v) and partitioned in organic solvents providing $12.89 \mathrm{~g}$ of the hexane (Hex-Ac), $31.18 \mathrm{~g}$ of the dichloromethane (Dic-Ac), $19.41 \mathrm{~g}$ of ethyl acetate (AcOEt-Ac) and $3.8 \mathrm{~g}$ of $n$-butanol $(n-\mathrm{BuOH})$ phases.

\subsection{Isolation of Chemical Compounds}

Dic-Ac (8.5 g) was chromatographed on a column (C1) with silica gel 60 (MachereyNagel, Düren, Germany) providing 58 fractions. Fraction 35 (500 mg) of C1 showed a yellowish precipitate soluble in methanol and was purified in a column with Sephadex 
LH-20 (SIGMA-ALDRICH ${ }^{\circledR}$, Saint Louis, MO, USA) and $\mathrm{MeOH}: \mathrm{CHCl}_{3}$ solution (1:1—v:v), yielding a mixture with 3 compounds (Ac-1), (Ac-2) and (Ac-3). The chromatographic process of the Dic-Ac is shown in Scheme 1.

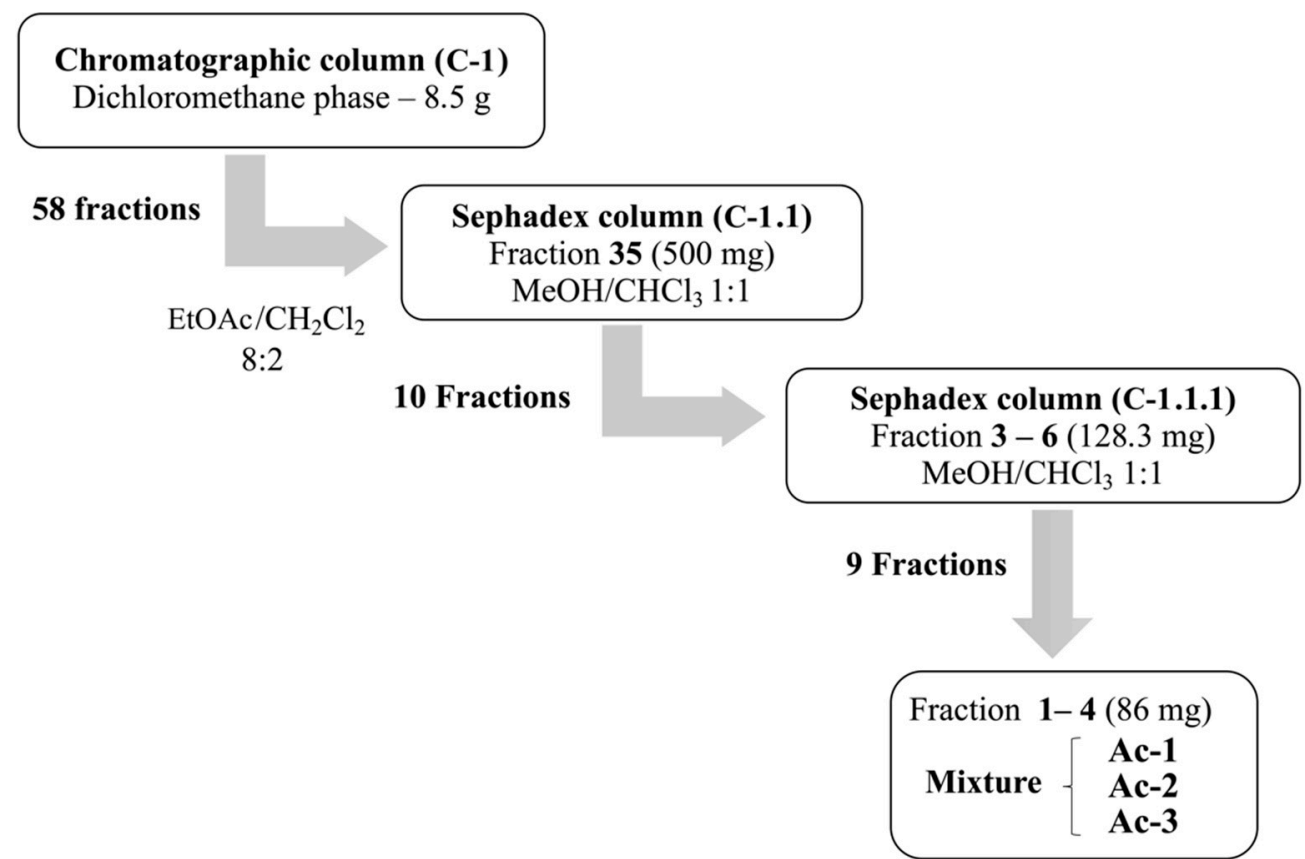

Scheme 1. Chromatographic process for obtaining of compounds Ac-1, Ac-2 and Ac-3 from dichloromethane phase (Dic-Ac).

\subsection{Spectral Analysis}

Fourier transform infrared spectroscopy (FTIR) was performed on FT-IR Spectrometer 400 equipment (PerkinElmer ${ }^{\circledR}$, Waltham, MA, USA), using $\mathrm{KBr}$ inserts for dispersing the samples and a scanning range between 4000 to $650 \mathrm{~cm}^{-1}$. The nuclear magnetic resonance spectra of hydrogen $\left({ }^{1} \mathrm{H}\right.$ NMR) and carbon $\left({ }^{13} \mathrm{C} N M R\right)$, were recorded in a BRUKER AVANCE III spectrometer (Bruker, Billerica, MA, USA) operating at $400 \mathrm{MHz}$ for ${ }^{1} \mathrm{H}$ and $100 \mathrm{MHz}$ for ${ }^{13} \mathrm{C}$, using the attached proton test (APT), heteronuclear single quantum coherence spectroscopy (HSQC) and heteronuclear multiple bond correlation (HMBC). The deuterated solvents used were $\mathrm{CDCl}_{3}$ and acetone- $\mathrm{d}_{6}$. The chemical shifts $(\delta)$ were expressed in parts per million (ppm), using the solvent itself as an internal reference and the coupling constants $(\mathrm{J})$ were given in Hz. The mass spectra were obtained on ESI-ITMS, model Amazon X (Bruker, Billerica, MA, USA).

\subsubsection{Cayaponoside $\mathrm{C}_{5 \mathrm{~b}}$ (Ac-1)}

Yellow amorphous powder (86 mg-in mixture); IR (KBr) $v_{\max }$ : 3042, 2970, 2924, 1685, 1485, 1388, 1300, 1076, $1026 \mathrm{~cm}^{-1} \cdot{ }^{1} \mathrm{H}$ and ${ }^{13} \mathrm{C}$ NMR (Acetone- $\mathrm{d}_{6}, 400$ and $100 \mathrm{MHz}$ ) spectroscopic data, see Table 1; ESIMS $m / z 661.26\left([\mathrm{M}-\mathrm{H}]^{-},\left(\mathrm{C}_{35} \mathrm{H}_{50} \mathrm{O}_{12}\right)\right.$.

\subsubsection{Cabenoside C (Ac-2)}

Yellow amorphous powder (86 mg-in mixture); ${ }^{1} \mathrm{H}$ and ${ }^{13} \mathrm{C}$ NMR (Acetone- $\mathrm{d}_{6}, 400$ and $100 \mathrm{MHz})$ spectroscopic data, see Table 1; ESIMS $m / z 545.06\left([\mathrm{M}-\mathrm{H}]^{-},\left(\mathrm{C}_{29} \mathrm{H}_{38} \mathrm{O}_{10}\right)\right.$.

\subsubsection{Fevicordin $\mathrm{C}_{2}$ Glucoside (Ac-3)}

Yellow amorphous powder (86 mg-in mixture); ${ }^{1} \mathrm{H}$ and ${ }^{13} \mathrm{C}$ NMR (Acetone-- $\mathrm{d}_{6}, 400$ and $100 \mathrm{MHz})$ spectroscopic data, see Table 1; ESIMS $m / z 659.15\left([\mathrm{M}-\mathrm{H}]^{-},\left(\mathrm{C}_{35} \mathrm{H}_{48} \mathrm{O}_{12}\right)\right.$. 
Table 1. ${ }^{1} \mathrm{H}$ and ${ }^{13} \mathrm{C}$ NMR spectroscopic data $\left(\delta\right.$, Acetone- $\mathrm{d}_{6}, 400$ and $100 \mathrm{MHz}$ ) of cayaponoside $\mathrm{C}_{5 \mathrm{~b}}$ (Ac- 1$)$, cabenoside $\mathrm{C}$ (Ac-2) and fevicordin $\mathrm{C}_{2}$ glucoside (Ac-3).

\begin{tabular}{|c|c|c|c|c|c|c|}
\hline \multirow[b]{2}{*}{$\mathrm{N}^{\mathrm{o}}$} & \multicolumn{2}{|c|}{ Cayaponoside $C_{5 b}$} & \multicolumn{2}{|c|}{ Cabenoside C } & \multicolumn{2}{|c|}{ Fevicordin $C_{2}$ Glucoside } \\
\hline & $\delta_{\mathrm{C}}$ & $\delta_{\mathrm{H}}(J$ in $\mathrm{Hz})$ & $\delta_{\mathrm{C}}$ & $\delta_{\mathrm{H}}(J$ in $\mathrm{Hz})$ & $\delta_{\mathrm{C}}$ & $\delta_{\mathrm{H}}(J$ in $\mathrm{Hz})$ \\
\hline 1 & 112.8 & \multirow[t]{5}{*}{$6.60(\mathrm{~s})$} & 112.7 & \multirow[t]{5}{*}{$6.58(\mathrm{~s})$} & 112.8 & \multirow[t]{5}{*}{$6.58(\mathrm{~s})$} \\
\hline 2 & 145.2 & & 144.9 & & 145.1 & \\
\hline 3 & 144.9 & & 145.1 & & 145.1 & \\
\hline 4 & 122.3 & & 122.3 & & 122.4 & \\
\hline 5 & 129.3 & & 127.8 & & 129.4 & \\
\hline 6 & 125.6 & $6.87(\mathrm{~d}, 10)$ & 125.6 & $6.88(\mathrm{~d}, 9.9)$ & 125.6 & $6.88(\mathrm{~d}, 9.9)$ \\
\hline 7 & 127.2 & $5.80(\mathrm{dd}, 6.2,10)$ & 126.9 & $5.82(\mathrm{dd}, 6.2,10)$ & 127.3 & $5.82(\mathrm{dd}, 6,2,10)$ \\
\hline 8 & 47.4 & \multirow[t]{4}{*}{$2.56(\mathrm{~m})$} & 47.6 & \multirow[t]{4}{*}{$2.54(\mathrm{~m})$} & 47.5 & \\
\hline 9 & 51.7 & & 50.5 & & 50.1 & \\
\hline 10 & 129.4 & & 129.2 & & 129.3 & \\
\hline 11 & 213.8 & & 212.7 & & 213.8 & \\
\hline \multirow{2}{*}{12} & \multirow{2}{*}{51.1} & $2.71(\mathrm{~d}, 14.9)$ & \multirow{2}{*}{49.7} & $2.87(\mathrm{~m})$ & \multirow{2}{*}{50.9} & \multirow{2}{*}{$\begin{array}{l}2.87(\mathrm{~m}) \\
2.67(\mathrm{~m})\end{array}$} \\
\hline & & \multirow{3}{*}{$3.05(\mathrm{~d}, 14.9)$} & & \multirow{3}{*}{$3.17(\mathrm{~m})$} & & \\
\hline 13 & 50.0 & & 49.0 & & 50.5 & \\
\hline 14 & 48.7 & & 49.5 & & 50.9 & \\
\hline 15 & 44.5 & $\begin{array}{l}1.33(\mathrm{sl}) \\
2.05(\mathrm{~m})\end{array}$ & 44.2 & $2.21(\mathrm{sl})$ & 48.6 & $1.33(\mathrm{sl})$ \\
\hline 16 & 71.2 & $4.34(t, 7.5)$ & 71.3 & $4.66(\mathrm{~m})$ & 71.4 & $4.48(\mathrm{~m})$ \\
\hline 17 & 58.7 & $2.53(\mathrm{~m})$ & 67.7 & $3.07(\mathrm{~m})$ & 58.8 & $2.66(\mathrm{~d}, 7.9)$ \\
\hline 18 & 17.9 & $0.95(\mathrm{~s})$ & 19.7 & $0.95(\mathrm{~s})$ & 20.0 & $0.95(\mathrm{~s})$ \\
\hline 19 & 26.7 & $1.20(\mathrm{~s})$ & 26.5 & $1.38(\mathrm{~s})$ & 29.8 & $1.20(\mathrm{~s})$ \\
\hline 20 & 79.8 & & 208.6 & & 79.9 & \\
\hline 21 & 25.2 & $1.38(\mathrm{~s})$ & 31.7 & $2.13(\mathrm{~s})$ & 26.0 & $1.37(\mathrm{~s})$ \\
\hline 22 & 215.6 & & & & 203.6 & \\
\hline 23 & $32.1 \mathrm{CH}_{2}$ & $2.86(\mathrm{~m})$ & & & $120.6 \mathrm{CH}$ & $6.81(\mathrm{~d}, 15.4)$ \\
\hline 24 & $37.9 \mathrm{CH}_{2}$ & $1.69(t, 7.9)$ & & & $155.3 \mathrm{CH}$ & $6.94(\mathrm{~d}, 15.3)$ \\
\hline 25 & 79.9 & & & & 69.7 & \\
\hline 26 & 29.4 & $1.13(\mathrm{~s})$ & & & 30.4 & $1.26(\mathrm{~s})$ \\
\hline 27 & 29.4 & $1.12(\mathrm{~s})$ & & & 29.7 & $1.27(\mathrm{~s})$ \\
\hline 28 & 11.2 & $2.21(\mathrm{~s})$ & 11.2 & $2.22(\mathrm{~s})$ & 11.2 & $2.22(\mathrm{~s})$ \\
\hline 30 & 20.2 & $1.01(\mathrm{~s})$ & 17.8 & $1.01(\mathrm{~s})$ & 19.7 & $1.01(\mathrm{~s})$ \\
\hline $1^{\prime}$ & 104.5 & $4.65(\mathrm{~d}, 7.4)$ & 104.6 & $4.65(\mathrm{~d}, 7.4)$ & 104.1 & $4.65(\mathrm{~d}, 7.4)$ \\
\hline $2^{\prime}$ & 74.3 & $3.59-3.40(\mathrm{~m})$ & 74.5 & $3.59-3.40(\mathrm{~m})$ & 74.6 & $3.59-3.40(\mathrm{~m})$ \\
\hline $3^{\prime}$ & 77.2 & $3.59-3.40(\mathrm{~m})$ & 77.2 & $3.59-3.40(\mathrm{~m})$ & 77.2 & $3.59-3.40(\mathrm{~m})$ \\
\hline $4^{\prime}$ & 70.7 & $3.59-3.40(\mathrm{~m})$ & 70.6 & $3.59-3.40(\mathrm{~m})$ & 70.3 & $3.59-3.40(\mathrm{~m})$ \\
\hline $5^{\prime}$ & 77.7 & $3.39(\mathrm{~m})$ & 77.7 & $3.39(\mathrm{~m})$ & 77.7 & $3.39(\mathrm{~m})$ \\
\hline $6^{\prime}$ & & $3.92(\mathrm{dd}, 2.8$ and 12$)$ & & $3.92(\mathrm{dd}, 2.8$ and 12$)$ & & $3.92(\mathrm{dd}, 2.8$ and 12$)$ \\
\hline $6^{\prime}$ & 62.0 & $3.80(\mathrm{dd}, 4.5$ and 12$)$ & 62.3 & $3.80(\mathrm{dd}, 4.5$ and 12$)$ & 62.3 & $3.80(\mathrm{dd}, 4.5$ and 12$)$ \\
\hline
\end{tabular}

\subsection{Quantification of Cayaponoside $C_{5 b}$ by Nuclear Magnetic Resonance ( ${ }^{1} H$-NMR)}

The acquisition of the ${ }^{1} \mathrm{H}-\mathrm{NMR}$ spectrum was performed on a Bruker Avance Neo 500 instrument operating at $500 \mathrm{MHz}$ (Bruker, Billerica, MA, USA). To obtain the ${ }^{1} \mathrm{H}$ NMR spectra, the following parameters were used: solvent acetone- $\mathrm{d}_{6}$; temperature: $25{ }^{\circ} \mathrm{C}$; number of scans: 64; receiver gain: auto; acquisition time: $2 \mathrm{~min}$. For quantification, TopSpin Eretic 2 software was used, which was calibrated using ethyl benzene (Bruker, Billerica, MA, USA) (8.16 mM) used as an external standard, using the same parameters described above. In the quantification, the peak area was used, which had the initial and final points of integration done manually. The concentration of Dic-Ac phase used to perform the tests was $20.45 \mathrm{mg} \mathrm{mL}^{-1}$. The experiment was carried out in triplicate. The value of cayaponoside $C_{5 b}$ present in the Dic-Ac is expressed in \%weight of cayaponoside $\mathrm{C}_{5 \mathrm{~b}} \pm$ standard deviation/weight of Dic-Ac phase $(\% w / w)$. 


\subsection{Toxicity in Human Erythrocytes}

The hemolytic activity assay was based on the method by Pinto et al. (2012) [15] with adaptations. To carry out this experiment, freshly collected blood samples of type $\mathrm{O}^{+}$ were collected in tubes containing EDTA anticoagulant. The erythrocytes were separated by centrifugation (3000 rpm, $5 \mathrm{~min}$ ), washed with saline and centrifuged again. This process was repeated 3 times for the complete removal of the plasma. After washing, the erythrocytes were resuspended in saline solution at a concentration of $1 \%$. The Hex-Ac and Dic-Ac samples were dissolved in saline and $0.2 \%$ Tween $80^{\mathrm{TM}}$ at concentrations of 10 , 100 and $1000 \mu \mathrm{g} \mathrm{mL}{ }^{-1}$. A mixture of $2 \mathrm{~mL}$ of the red blood cell suspension $+500 \mu \mathrm{L}$ of the test solutions was made and left for $1 \mathrm{~h}$ at room temperature for hemolysis to occur. Concomitantly, negative control (saline $+0.2 \%$ Tween $80^{\mathrm{TM}}$ ) and positive control ( $1 \%$ Triton $\mathrm{X}-100^{\mathrm{TM}}$ ) were used for hemolysis.

After the incubation period, the samples were centrifuged and the overflowing liquid was subjected to analysis in a UV-VIS SHIMADZU spectrophotometer (Shimadzu, Kyoto, Japan) at $540 \mathrm{~nm}$ wavelength. The hemolytic potential of the tested samples was calculated from the following Equation (1):

$$
\mathrm{Hp}(\%)=[(\mathrm{Ea}-\mathrm{Ba}) / \mathrm{Ta}] \times 100 \%,
$$

where $\mathrm{Hp}=$ Hemolytic potential $(\%) ;$ Ea $=$ Extract absorbance; $\mathrm{Ba}=$ Blank absorbance (negative control); Ta = Triton- $\mathrm{X} 100$ absorbance (positive control).

\subsection{Biological Assays}

\subsubsection{Experimental Animals and Ethical Procedures}

In this study, adult (about 60 days old) albino Swiss mice (Mus musculus) were used, weighing between 25 and $35 \mathrm{~g}$ - from the State University of Paraíba's bioterium-and acclimatized for 15 days in the Laboratory of Pharmacological Tests, where they were used to carry out the acute toxicity and inflammation experiments.

The animals were housed in polyethylene cages with stainless steel grids and wood shavings as a cover, with free access to water and balanced feed, kept in an environment with a temperature of $22 \pm 2{ }^{\circ} \mathrm{C}$ and controlled light, providing a light-dark $12 \mathrm{~h}$ cycle. All animals were fasted, with the food removed about $4 \mathrm{~h}$ before the beginning of the experiments. During the tests, the animals had free access to water intake. The animals were kept in accordance with the international standards of the Experimental Animal Laboratory Council (ICLAS).

All experiments were carried out in accordance with the standards established by the Brazilian Society for Laboratory Animal Science (SBCAL) and with the standards established by the National Institute of Health Guide for Care and Use of Laboratory Animals. The Ethics Committee on Use in Animals (CEUA-UEPB) approved this study, which was registered as process No. 002/2020 approved on 14 October 2020.

\subsubsection{Acute Toxicity}

The assessment of acute toxicity was employed using the methodology recommended by the Organization for Economic Cooperation and Development-Guideline 423 [16]. Female mice (60 days) were randomly assigned to two groups of three animals. A single dose was administered orally to the animals in the test group. The control group $(n=3)$ received the vehicle (water $+5 \%$ Tween $80^{\mathrm{TM}}-v: v$ ) and the treated group $(n=3)$ received Dic-Ac at a dose of $2000 \mathrm{mg} \mathrm{kg}^{-1}$.

The animals were observed in the first two hours and then every $24 \mathrm{~h}$ daily, for 14 days, after the administration of Dic-Ac. The evaluation was carried out using the hypocratic screening method and, in addition, the mass, water and feed consumption were evaluated daily. On the 14th day, the animals were anesthetized with ketamine and xylazine (2:1-v:v) intraperitoneally, and then blood was collected by cardiac puncture for hematological and biochemical tests. Euthanasia of the animals was accomplished using 
the same combination of anesthetics in a lethal dose. The liver, kidney, spleen, lung and heart organs were collected for macroscopic analysis, as well as for the determination of the organ index calculated according to the formula (2):

$$
\text { Relative weight }=(\text { Organ weight } / \text { Animal weight }) \times 100 \%
$$

Subsequently, the entire experiment was repeated according to the same initial conditions to confirm the results obtained. The results found were analyzed and evaluated in the same way and expressed as an average between groups.

\subsubsection{Anti-Inflammatory Activity-Carrageenan-Induced Paw Edema}

In this test, the animals were divided into 5 groups $(n=8)$. The groups received the substances orally: Dic-Ac at doses of 30, 15 and $7.5 \mathrm{mg} \mathrm{kg}^{-1}$, a control group (water $+5 \%$ Tween $80^{\mathrm{TM}}$ ) and a standard drug group (dexamethasone $10 \mathrm{mg} \mathrm{kg}^{-1}$ ).

One hour after the treatment of each group, the inflammatory process was induced through an intraplantar injection (i.pl.) of $50 \mu \mathrm{L}$ of carrageenan (1\%) in the right hind paw. The animal's other paw was also analyzed for volume measurement and compared with the paws that received carrageenan. Paw volumes were measured before induction by the phlogistic agent and, after induction, at pre-established intervals of 1, 2, 3, 4 and $5 \mathrm{~h}$ after the administration of carrageenan. The volume of the edema $(\mathrm{mL})$ was recorded using a plethysmometer (Ugo Basile ${ }^{\circledR}$, Gemonio, Italy). The animal's posterior paw was submerged until the tibio-tarsal junction in the device's reading chamber. The volume of liquid displaced was recorded digitally and corresponded to the volume of the paw. The results were expressed as the difference in volume $(\mathrm{mL})$ between the paw that received carrageenan and the contralateral paw that did not receive carrageenan.

\subsubsection{Anti-Tumor Activity in Ehrlich's Carcinoma}

In this experiment, tumor cells from the Ehrlich Carcinoma lineage (solid form) were removed from donor animals with eight days of implantation, through ascites aspiration and introduced into the recipient animals, subcutaneously in the right axillary region, in a concentration of $2.5 \times 10^{7}$ cells $/ \mathrm{mL}$ [17]. The recipient animals were divided into four groups $(n=5)$ subdivided into a control group ( $0.9 \%$ saline), a standard group (cisplatin $2.5 \mathrm{mg} \mathrm{kg}^{-1}$ ) and treated groups (Dic-Ac $15 \mathrm{mg} \mathrm{kg}^{-1}$ and $30 \mathrm{mg} \mathrm{kg}^{-1}$ ). Treatment was started after $24 \mathrm{~h}$ of the tumor's implantation and the compounds' tests were administered orally for seven days. On the eighth day, the animals were sacrificed in $\mathrm{C}_{2}$ chamber and the tumors were removed and separated by the group, dissected, weighed and then the difference between the control, standard and treated groups was calculated to obtain the tumor inhibition index according to the Equation (3):

$$
\mathrm{TWI} \%=[\mathrm{C}-\mathrm{T} / \mathrm{C}] \times 100 \%
$$

where TWI \% = percentage of tumor growth inhibition, $\mathrm{C}=$ average tumor weight of animals in the control group, $\mathrm{T}=$ average weight of animals in the treated group [18].

\subsubsection{Data Analysis}

The toxicity experiments were statistically evaluated through $t$ test, with a 95\% confidence interval, using the Graph Pad Prism 8.0 software. Values of " $p$ " less than 0.05 $(p<0.05)$ were considered as indicative of significance. The carrageenan-induced paw edema experiments were evaluated using two-way analysis of variance (ANOVA), followed by the Bonferroni test with a 95\% confidence interval, using the Graph Pad Prism 5.0 software. Values of " $p$ " less than $0.05(p<0.05)$ were considered as indicative of significance. The Ehrlich's carcinoma experiments were evaluated using the statistical analysis using two-way ANOVA followed by the Tukey's multiple comparison test. 


\section{Results and Discussion}

\subsection{Caracterization of Mixture Ac-1, Ac-2 e Ac-3}

The IR spectrum (Figure S1) showed a wide band at $3402 \mathrm{~cm}^{-1}$ characteristic of O-H stretch, bands at 2970 and $2924 \mathrm{~cm}^{-1}$ typical of $\mathrm{C}-\mathrm{H}$ bonding of carbon sp ${ }^{3}$, in addition to a medium intensity band in $1685 \mathrm{~cm}^{-1}$ suggesting the presence of ketone carbonyl. The two bands at 1485 and $1388 \mathrm{~cm}^{-1}$ indicate bend of the $\mathrm{C}-\mathrm{H}$ bond, besides a band at $1076 \mathrm{~cm}^{-1}$ suggestive of the $\mathrm{C}-\mathrm{O}$ bond [19].

In the ${ }^{1} \mathrm{H}$ NMR data $(\delta$, Acetone-d6, $400 \mathrm{MHz})$ a signal envelope between $\delta_{\mathrm{H}} 2.5-0.95$ (Figure S2) suggestive of hydrogens linked to $\mathrm{sp}^{3}$ carbon was visualized, of which seven of them were associated with groups methyl at $\delta_{\mathrm{H}} 0.95$ (C-18); 1.20 (C-19); 1.38 (C-21); 1.13 (C-26); 1.12 (C-27); 2.21 (C-28) and 1.01 (C-30). In the region between $\delta_{\mathrm{H}} 5.80-6.94$ (Figure S3), typical signs of protons linked to $\mathrm{sp}^{2}$ carbons were seen. In addition, singlets in $\delta_{\mathrm{H}} 6.60,6.58$ and 6.55 suggest the presence of aromatic hydrogens present in norcucurbitacin structures [20]. Through the observation of the integral of these last signs, it was possible to define that the sample was a mixture of three compounds.

The expansion of ${ }^{1} \mathrm{H}$ NMR spectrum (Figure S4) showed the presence of the signals between $\delta_{\mathrm{H}} 3.59$ and $3.40\left(\mathrm{~m}, \mathrm{H}-2^{\prime}, \mathrm{H}-3^{\prime}, \mathrm{H}-4^{\prime}\right.$ and $\left.\mathrm{H}-5^{\prime}\right)$ indicative of an osidic unit, in addition to a doublet at $\delta_{\mathrm{H}} 4.65\left(\mathrm{~J}=7.4 \mathrm{~Hz}, \mathrm{H}-1^{\prime}\right)$ characteristic of anomeric proton. Such data suggest the presence of a $\beta$-glucose type sugar molecule $[20,21]$.

The ${ }^{13} \mathrm{C}$ NMR spectrum (Figure S5) allowed the visualization of approximately 80 signals, which confirmed the presence of more than one compound in the analyzed fraction. Two signals were observed in the low field $\left(\delta_{\mathrm{C}} 213.8\right.$ and 212.7-Figure S6) suggestive of ketone carbonyls present in tetracyclic triterpenes of the cucurbitan nucleus [22] corroborating the IR spectrum. It was also possible to note signs in the aromatic ring region at $\delta_{\mathrm{C}}$ $112.8 ; 145.2 ; 144.9 ; 122.3 ; 129.3$ and 129.4 (Figure S7) referring to the carbons of ring A of the tetracyclic nucleus C-1, C-2, C-3, C-4, C-5 and C-10, in addition to signals between $\delta_{\mathrm{C}}$ 70.3-77.7 (Figure S8) that are typical of sugar carbons, which reinforces the presence of a glycosidic unit linked to a triterpene nucleus.

A signal was observed at approximately $\delta_{\mathrm{C}} 58.7$ (Figure S9) which is characteristic of C-17 with a side chain directly connected to it [20]. In this side chain, the signals at $\delta_{\mathrm{C}} 29.6(\mathrm{C}-26)$ and $\delta_{\mathrm{C}} 29.4$ (C-27) (Figure S10), suggestive of methyl carbons, and a signal at $\delta_{\mathrm{C}} 79.6$ (C-25) was identified, making it possible to deduce that C-25 supported two methyl and one hydroxyl [23]. These signals were attributed to the major compound called the cayaponoside $\mathrm{C}_{5 \mathrm{~b}}$ (Ac-1). However, a signal at $\delta_{\mathrm{C}} 67.5$ (Figure S8) referring to carbon 17 was also seen, when it does not support a side chain and another signal at $\delta_{\mathrm{C}} 208.6$ compatible with ketone carbon at position C-20 [24]. The presence of this value for carbon 17 was reinforced by the interactions seen in the HSQC heteronuclear correlation map (Figure S11) between $\delta_{\mathrm{H}} 3.07 / \delta_{\mathrm{C}} 67.8$ and in HMBC (Figure S12) between $\delta_{\mathrm{H}} 3.07 / \delta_{\mathrm{C}} 49.5$, 72.0, 208.4 and 19.7 confirming that the second compound did not have the side chain and that it was the cabenoside $\mathrm{C}$ (Ac-2). The molecular formulas $\mathrm{C}_{35} \mathrm{H}_{50} \mathrm{O}_{12}$ and $\mathrm{C}_{29} \mathrm{H}_{38} \mathrm{O}_{10}$ were determined by negative-mode ESI-MS measurement of the molecular ions at $\mathrm{m} / \mathrm{z}$ $661.26[\mathrm{M}-\mathrm{H}]^{-}$and $545.06[\mathrm{M}-\mathrm{H}]^{-}$of Ac-1 and Ac-2, respectively (Figures S13 and S14).

For the carbons $\mathrm{C}-23$ and $\mathrm{C}-24$ of the side chain of the cayaponoside $\mathrm{C}_{5 \mathrm{~b}}$ (Ac-2) the correlations between $\delta_{\mathrm{H}} 2.85 / \delta_{\mathrm{C}} 32.1$ and $\delta_{\mathrm{H}} 1.69 / \delta_{\mathrm{C}} 38.0$, in the HSQC (Figure S11) and between $\delta_{\mathrm{H}} 2.86 / \delta_{\mathrm{C}} 37.7 ; 215.3$ and $\delta_{\mathrm{H}} 1.69 / \delta_{\mathrm{C}} 215.4 ; 32.0$ and 29.3, in HMBC (Figure S12), respectively, were visualized, confirming that these two carbons have $\mathrm{sp}^{3}$ hybridization and that the values $\delta_{\mathrm{C}}$ in $\delta_{\mathrm{C}} 32.0,37.7,215.4$, and 29.3 can be attributed to the carbons of positions 23, 24, 22 and 26-27, respectively. However, the occurrence of the signals at $\delta_{\mathrm{C}} 120.6$ and 155.3 points to the presence of unsaturated carbons at positions 23 and 24 indicating the presence of an isomer of the compound Ac-2, not yet evidenced in the literature.

Two doublets in the ${ }^{1} \mathrm{H}$ NMR spectrum were recorded at $\delta_{\mathrm{H}} 6.81$ and 6.94, with coupling constants of $J=15.4 \mathrm{~Hz}$, together with the signal at $\delta_{\mathrm{C}} 203.6$ seen in ${ }^{13} \mathrm{C}$ NMR, suggesting the presence of vinyl hydrogens in an $\alpha, \beta$-unsaturated carbonyl. To support 
these data, the signals between $\delta_{\mathrm{H}} 6.81 / \delta_{\mathrm{C}} 120.6$ and $\delta_{\mathrm{H}} 6.94 / \delta_{\mathrm{C}} 155.3$ were also visualized in the heteronuclear correlation map-HSQC, and in the HMBC, the couplings between $\delta_{\mathrm{H}}$ $6.81 / \delta_{\mathrm{C}} 70.4,155.2$ and 203.5 and $\delta_{\mathrm{H}} 6.94 / \delta_{\mathrm{C}} 70.4,120.3,203.3$ and 29.4, confirming 30.4, $70.4,120.3,155.2$ and 203.3 for positions 26, 25, 23, 24 and 22, respectively. The molecular formula $\mathrm{C}_{35} \mathrm{H}_{48} \mathrm{O}_{12}$ was determined by ESIMS at m/z $659.15[\mathrm{M}-\mathrm{H}]^{-}$and confirmed Ac-3 (Figure S15).

According to the interpretation of the IR, MS and NMR signals, using uni and bidimensional techniques and, aided by the comparison with the data described in the literature $[20,21,23]$, it was possible to deduce that the mixture of the compounds contained norcucurbitacin, which have an aromatic ring, commonly designated as a 2,3-di-O-substituted derivative. Three compounds were identified in this mixture (Figure 1), two of which are already known in the literature: cayaponoside $C_{5 b}$ and cabenoside $C$, as well as a new 29-norcucurbitacin named of fevicordin C2 glycoside. Norcucurbitacins are a subclass of cucurbitacins and have structures known for the absence of methyl at position C-28 or C-29. They have already been shown in species of the genus Fevillea, Cayaponia and Wilbrandia, all belonging to the family Cucurbitaceae [25], but identified for the first time in the genus Apodanthera.
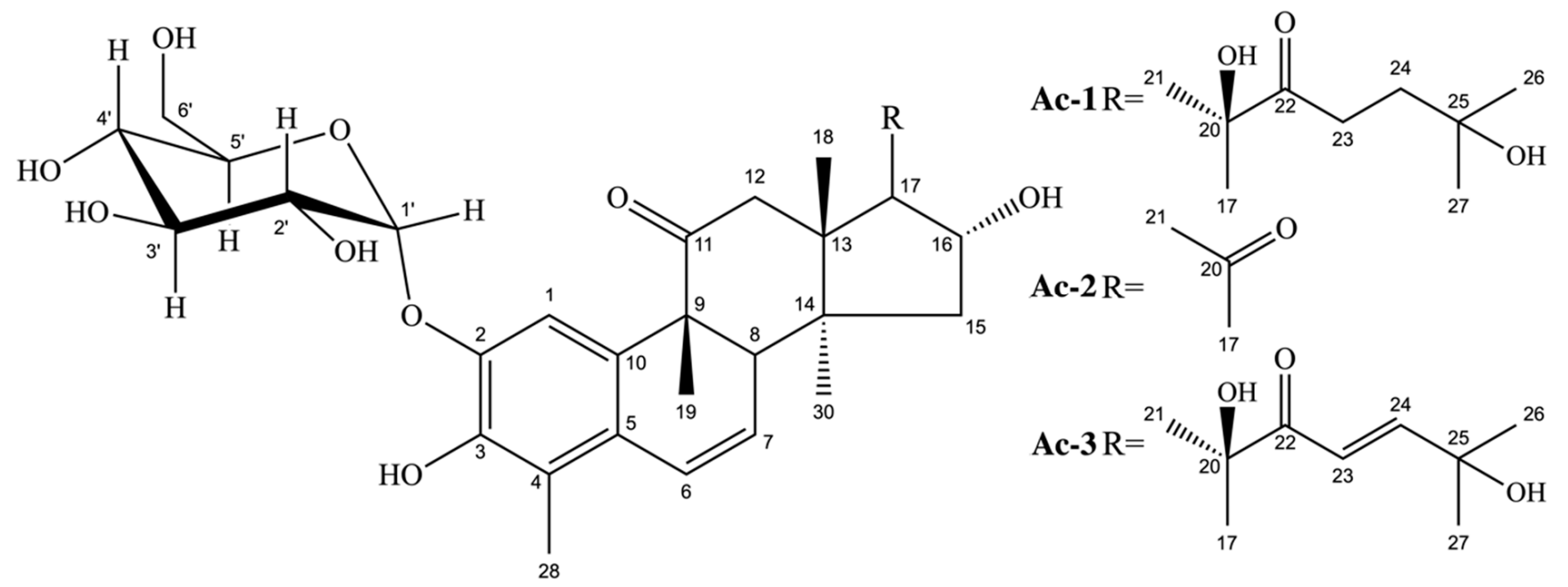

Figure 1. Chemical structures of cayaponoside $C_{5 b}$ (Ac-1), cabenoside $C$ (Ac-2) and fevicordin $C_{2}$ glucoside (Ac-3).

The Cucurbitaceae family is known for the variety of secondary metabolites it produces, especially cucurbitacins, as demonstrated by Kaushik et al. (2015) [9]. Previous studies carried out with aqueous extracts from the vegetable drug of $A$. congestiflora, in different particle sizes, showed a high concentration of saponins (18.9-37.5\%) in the spectroscopic analysis made in a spectrophotometer using diosgenin as a standard [26]. However, no study was carried out demonstrating the concentration of isolated compounds present in the extracts of species of the genus Apodanthera. Thus, we performed the absolute quantification of the cayaponoside $C_{5 b}$, present in the dichloromethane phase, using the TopicSpin Eretic 2 method from the studies of evaluation of ${ }^{1} \mathrm{H}$ NMR spectra [27].

Initially, the signals seen in the ${ }^{1} \mathrm{H}$ NMR spectrum of the dichloromethane phase that referred to the cayaponoside $\mathrm{C}_{5 \mathrm{~b}}$ were assigned (Figure S16). The typical signal at $\delta_{\mathrm{H}} 6.60$ of the aromatic A ring, the signals at $\delta_{\mathrm{H}} 6.87(\mathrm{~d}, 10.0 \mathrm{~Hz}, 1 \mathrm{H})$ and $\delta_{\mathrm{H}} 5.50(\mathrm{dd}, 6.2$ and $10.0 \mathrm{~Hz}$, $1 \mathrm{H})$ referring to the olefinic protons in C-6 and C-7, respectively, in addition to the terminal methyls at $\delta_{\mathrm{H}} 1.12(\mathrm{~s}, 3 \mathrm{H})$ and $\delta_{\mathrm{H}} 1.13(\mathrm{~s}, 3 \mathrm{H})$ were visualized for Ac- 1 . The signal at $\delta_{\mathrm{H}}$ 1.13 (Figures S17-S19) was used to quantify the cayaponoside $\mathrm{C}_{5 \mathrm{~b}}$ in the dichloromethane extract, as this signal did not show any overlap with other signals in the ${ }^{1} \mathrm{H}$ NMR spectrum. Thus, in this experiment we were able to reveal that this compound represents about $7 \%$ $(\mathrm{SD}=0.02$ and $\mathrm{CV}=1.45)$ of the dichloromethane phase of A. congestiflora $(\% w / w)$. 


\subsection{Hemolytic Activity}

The potential of Dic-Ac to promote damage to the erythrocyte membrane was assessed by the hemolytic assay, which allows investigating the ability of a product to promote the formation of pores or cause rupture of the erythrocyte membrane. Hemolysis did not occur for concentrations of 10 and $100 \mu \mathrm{g} \mathrm{mL}^{-1}$. Therefore, the hemolytic potential $(\mathrm{Hp})$ was calculated only for the concentration of $1000 \mu \mathrm{g} \mathrm{mL} \mathrm{g}^{-1}$, with $\mathrm{Hp}=0.28 \%$ for Dic-Ac.

Although these studies report low or no toxicity, the fact that saponins are present in the extracts could lead to greater toxicity, since saponins, due to their amphiphilic character, generally present interactions with cell membranes, including hemolytic and ichthyotoxic action [28].

The hemolytic potential of the roots from A. Congestiflora was assessed by Pereira (2017) [13] and Videres (2017) [14], using the similar assay. In both, no evidence of hemolysis was found in the tested extracts.

\subsection{Acute Toxicity}

The animals were treated with Dic-Ac at a dose of $2000 \mathrm{mg} \mathrm{kg}^{-1}$ orally, in view of the finding of signs of toxicity by the animals in a study by Pereira (2017) [29], whereby the ethyl acetate phase was obtained from the roots of the plant.

In the first stage of the evaluation, called the hypocratic test, clinical signs of toxicity were observed. Therefore, the animals showed several behavioral changes, especially $4 \mathrm{~h}$ after the administration of the phase, such as: increased urination and defecation, loss of straightening reflex, ataxia, eyelid ptosis, tachycardia and respiratory changes. In addition, the Dic-Ac caused mortality of an animal within $24 \mathrm{~h}$. This last event motivated the repetition of the experiment, according to the OECD protocol 423 [16], with a death being confirmed again over the 14 days.

In Table 2, an increase in water consumption and a reduction in feed consumption by the animals tested can be observed in relation to those in the control group, suggesting signs of toxicity for consideration, albeit discrete, since the animals did not present weight gain in the same proportion as those of the control group.

Table 2. Weight evolution and water/feed consumption of the control and treated groups with Dic-Ac in the acute toxicity experiment $\left(2000 \mathrm{mg} \mathrm{kg}^{-1}\right)$.

\begin{tabular}{ccccc}
\hline \multirow{2}{*}{ Group } & \multicolumn{2}{c}{ Weight $(\mathbf{g})$} & $\begin{array}{c}\text { Water Consumption } \\
\text { by Animal }(\mathbf{m L})\end{array}$ & $\begin{array}{c}\text { Feed Consumption } \\
\text { by Animal (g) }\end{array}$ \\
\cline { 2 - 5 } & Initial & Final & & \\
\hline Control & $28.2 \pm 1.58$ & $36.0 \pm 1.01$ & $9.97 \pm 0.15$ & $7.89 \pm 0.25$ \\
Treated with Dic-Ac & $26.3 \pm 1.81$ & $30.6 \pm 1.47^{*}$ & $12.84 \pm 0.87 *$ & $6.49 \pm 0.98$ \\
\hline \multirow{*}{*}{$p<0.05$. Significant after two-way analysis of variance (ANOVA) followed by the Bonferroni test with a 95\% } \\
confidence interval, when compared to the control group.
\end{tabular}

The reduction in feed consumption by the group treated with Dic-Ac corroborates the data on the final weight of the animals and denotes a lower weight gain than that obtained by the control group over the 14 days of the experiment, suggesting a possible toxicity linked to the product in the tested dose. This fact can be explained by the ability of some toxic active ingredients to cause apathy, anorexia and diarrhea, symptoms that can lead to weight loss or progressive weight loss in exposed individuals [30].

In this regard, throughout the chemical investigation of Dic-Ac carried out in the present work, 3 cucurbitacins were isolated (Ac-1, Ac-2 and Ac-3). Most compounds belonging to this class have high toxicity and a wide range of biological activities, including cytotoxic activity [24]. The presence of these constituents may explain the relative toxicity of Dic-Ac, although in vitro tests for hemolytic activity in this phase have not shown significant toxicity. 
There was also a significant increase in the size and mass of the liver of the animals treated with Dic-Ac in the dose used (Table 3), suggestive of hepatomegaly caused by the constituents present. We can suggest that in the dose used, Dic-Ac may be involved in metabolic pathways that are directly linked to the liver, since it is responsible for the metabolism of various endogenous and exogenous substances [31]. Furthermore, an increase in serum levels of transaminases was also observed (Table 4), important enzymes in liver damage events, corroborating the hepatomegaly found in the macroscopic and quantitative evaluation.

Table 3. Organs absolute mass of control and treated with Dic-Ac groups in the acute toxicity experiment $\left(2000 \mathrm{mg} \mathrm{kg}^{-1}\right)$.

\begin{tabular}{cccccc}
\hline \multirow{2}{*}{ Group } & \multicolumn{5}{c}{ Organ Index } \\
\cline { 2 - 6 } & Lungs & Heart & Kidney & Liver & Spleen \\
\hline Control & $0.15 \pm 0.01$ & $0.13 \pm 0.01$ & $0.42 \pm 0.03$ & $1.66 \pm 0.04$ & $0.22 \pm 0.07$ \\
Treated with Dic-Ac & $0.14 \pm 0.02$ & $0.12 \pm 0.02$ & $0.46 \pm 0.01$ & $2.47 \pm 0.06^{*}$ & $0.24 \pm 0.03$ \\
\hline
\end{tabular}

${ }^{*} p<0.05$. Significant after two-way analysis of variance (ANOVA) followed by the Bonferroni test with a $95 \%$ confidence interval, when compared to the control group.

Table 4. Biochemical and hematological parameters of the control and treated groups with the Dic-Ac in the acute toxicity experiment $\left(2000 \mathrm{mg} \mathrm{kg}^{-1}\right)$.

\begin{tabular}{|c|c|c|c|}
\hline & Test & Control & Treated with Dic-Ac \\
\hline \multirow{12}{*}{ Biochemical } & Urea $\left(\mathrm{mg} \mathrm{dL}^{-1}\right)$ & $16.43 \pm 2.03$ & $18.1 \pm 1.33$ \\
\hline & Creatinine $\left(\mathrm{mg} \mathrm{dL}^{-1}\right)$ & $0.41 \pm 0.09$ & $0.42 \pm 0.03$ \\
\hline & $\operatorname{AST}\left(\mathrm{U} \mathrm{L}^{-1}\right)$ & $10.93 \pm 4.30$ & $12.42 \pm 5.61$ \\
\hline & $\operatorname{ALT}\left(\mathrm{U} \mathrm{L}^{-1}\right)$ & $16.57 \pm 9.50$ & $19.28 \pm 8.65$ \\
\hline & Alkaline phosphatase $\left(\mathrm{U} \mathrm{L}^{-1}\right)$ & $26.42 \pm 6.71$ & $31.36 \pm 8.24$ \\
\hline & Total protein $\left(\mathrm{g} \mathrm{dL}^{-1}\right)$ & $3.67 \pm 1.12$ & $4.63 \pm 0.62$ \\
\hline & Albumin $\left(\mathrm{g} \mathrm{dL}^{-1}\right)$ & $1.44 \pm 0.26$ & $1.68 \pm 0.11$ \\
\hline & Glucose $\left(\mathrm{mg} \mathrm{dL}^{-1}\right)$ & $69.00 \pm 1.73$ & $49.00 \pm 2.33 *$ \\
\hline & Total cholesterol $\left(\mathrm{mg} \mathrm{dL}^{-1}\right)$ & $149.70 \pm 10.80$ & $116.30 \pm 3.28$ * \\
\hline & Triglycerides $\left(\mathrm{mg} \mathrm{dL}^{-1}\right)$ & $47.33 \pm 7.48$ & $43.67 \pm 3.61$ \\
\hline & Total bilirubin $\left(\mathrm{mg} \mathrm{dL}^{-1}\right)$ & $0.62 \pm 0.17$ & $0.61 \pm 0.12$ \\
\hline & Gamma-GT (mg dL $\left.{ }^{-1}\right)$ & $20.36 \pm 4.29$ & $19.37 \pm 3.84$ \\
\hline \multirow{12}{*}{ Hematological } & Red blood cells count $\left(\mathrm{mm}^{3}\right)$ & $5.29 \pm 0.33$ & $5,74 \pm 0,41$ \\
\hline & Hemoglobin concentration $\left(\mathrm{g} \mathrm{dL}^{-1}\right)$ & $15.14 \pm 0.03$ & $14,63 \pm 0.05$ \\
\hline & Hematocrit $(\%)$ & $46.00 \pm 1.31$ & $44.00 \pm 1.46$ \\
\hline & $\mathrm{MCV}(\mathrm{fL})$ & $45.53 \pm 0.05$ & $44.24 \pm 0.07$ \\
\hline & $\mathrm{MCH}(\mathrm{pg})$ & $16.54 \pm 0.07$ & $15.39 \pm 0.01$ \\
\hline & $\mathrm{MCHC}(\%)$ & $35.67 \pm 0.32$ & $34.93 \pm 0.28$ \\
\hline & Platelet count $\left(\mathrm{mm}^{3}\right)$ & $162.08 \pm 0.26$ & $148.68 \pm 0.21$ \\
\hline & White blood cells count $\left(\mathrm{mm}^{3}\right)$ & $6.00 \pm 0.48$ & $4.50 \pm 0.29$ \\
\hline & Segmented neutrophils (\%) & 40 & 45 \\
\hline & Eosinophils (\%) & 01 & 04 \\
\hline & Lymphocytes (\%) & 57 & 50 \\
\hline & Monocytes (\%) & 02 & 01 \\
\hline
\end{tabular}

$\overline{\mathrm{MCV}}=$ mean corpuscular volume; $\mathrm{HCV}=$ mean corpuscular hemoglobin; $\mathrm{MCHC}=$ mean corpuscular hemoglobin concentration. ${ }^{*} p<0.05$. Significant after $t$ test with a $95 \%$ confidence interval, when compared to the control group.

The toxicity shown in the in vivo assay may not be directly related to red cell toxicity. This proposition was confirmed by the complete blood count of the animals' peripheral blood (Table 4), which showed no changes in hematological parameters, corroborating the data obtained in vitro in the hemolysis test.

Different to the results of the macroscopic analysis of the liver of animals submitted to the acute toxicity test, no significant changes were found in the evaluation of other liver 
enzymes and metabolites directly involved in hepatic pathways, such as Gamma-GT and bilirubin. Significant changes in glucose and total cholesterol levels were only seen in the treated group compared to the control. In this sense, it is necessary to carry out more specific assessments of liver tissue lesions, such as immunohistochemical and ultrastructural assessment of the lesions, as they are techniques that exhibit a wide dimension of the degree of hepatic impairment induced by natural products [32].

The toxicity of an exogenous compound can manifest itself through cell damage in different tissue structures, triggering physiological changes, mainly in liver and kidney function. Metabolism in general is also susceptible to changes, which were observed in this study through hematological and biochemical parameters. It is for this reason that the analysis of the toxicity of any substance is a complex and multifactorial process, since the manifestation of the damage can be silent, apparent or even expressed due to multiple exposures to the supposedly toxic agent. Because of these factors, this experiment is an initial and preliminary step in the study of the toxicity of any agent, including those of natural origin [16].

Therefore, based on these premises, it is not possible to establish or seal the toxicity of a substance in a simple way. In this sense, despite the apparent preliminary liver damage, there were no significant changes in the other organs analyzed and in most serological tests, mainly in renal function.

\subsection{Anti-Inflammatory Activity}

To evaluate the anti-inflammatory potential of dichloromethane phase (Dic-Ac), the carrageenan-induced paw edema model at doses of 7.5, 15 and $30 \mathrm{mg} \mathrm{kg}^{-1}$ per animal mass was used. The doses chosen were based on experiments previously carried out by our research group, considering that from the assessment of acute toxicity at the dose of $2000 \mathrm{mg} \mathrm{kg}^{-1}$, the death of an animal was found. The experiment was repeated with a dose of $300 \mathrm{mg} \mathrm{kg}^{-1}$, which corroborated the result obtained in the previous test. Thus, it was chosen as the highest dose to be tested at $30 \mathrm{mg} \mathrm{kg}^{-1}$, corresponding to $10 \%$ of the second highest dose recommended by the OECD protocol.

It was observed that the Dic-Ac reduced edema in a continuous and sustained way during the $5 \mathrm{~h}$ of observation, with no statistical difference between the doses tested (Figure 2). In this perspective, it is suggested that the effect of this phase is not dosedependent, something positive, as this fact allows a pronounced anti-inflammatory effect to be obtained even with the administration of low doses, which would supposedly lead to a lower risk of toxicity.

The highest percentage of edema inhibition (Table 5) occurred after $2 \mathrm{~h}$, at the dose of $7.5 \mathrm{mg} \mathrm{kg}^{-1}(66.6 \%)$, a fact that was repeated in a similar way until the fourth hour of observation. In the fifth hour, the most effective dose was $30 \mathrm{mg} \mathrm{kg}^{-1}$ (64.3\%). This phenomenon can be explained by the fact that the administration of the highest dose is able to maintain a sufficient plasma concentration to maintain the inhibition of inflammation for a longer time. In this case, a further evaluation of the pharmacokinetics of that phase is necessary to verify and validate these preliminary observations.

The anti-inflammatory activity of Apodanthera congestiflora has been cited by ethnopharmacological surveys and in previous studies carried out with its roots, which also validated popular knowledge about this species $[15,16]$. It is worth noting that the three norcucurbitacins evidenced in the study of chemical bioprospecting were present in the Dic-Ac and may be involved in the anti-inflammatory activity observed in pharmacological tests $[20,23]$. 


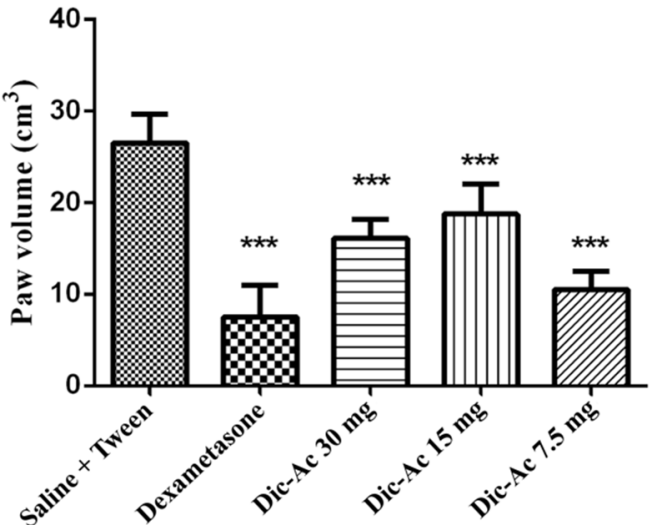

Treatment (after 1h)

(a)

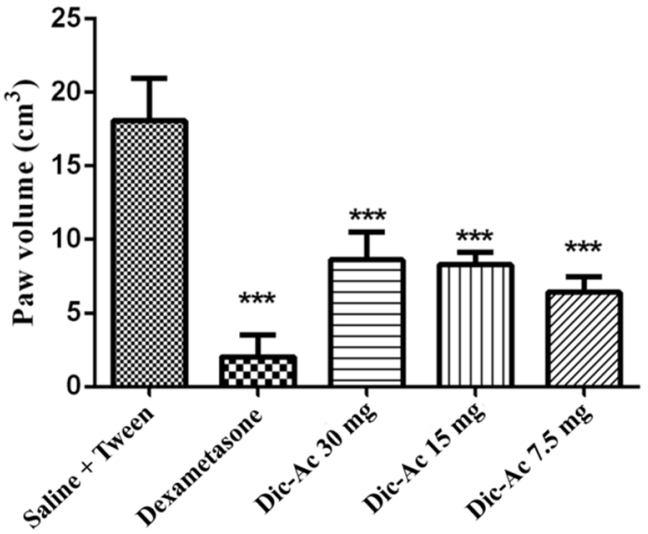

Treatment (after 3h)

(c)

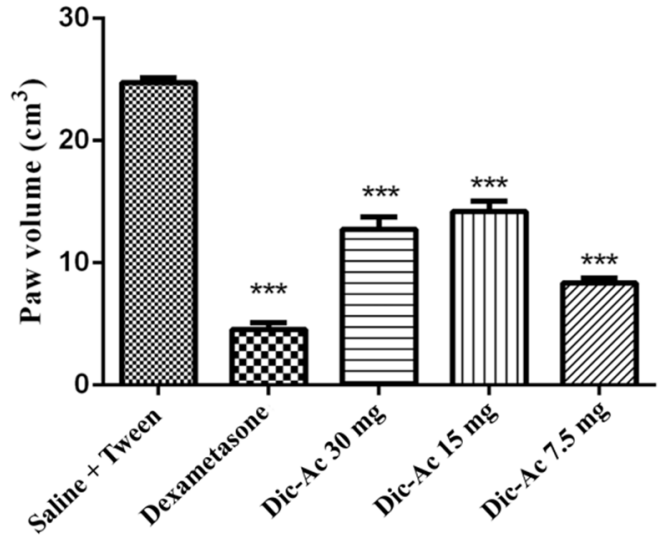

Treatment (after 2h)

(b)

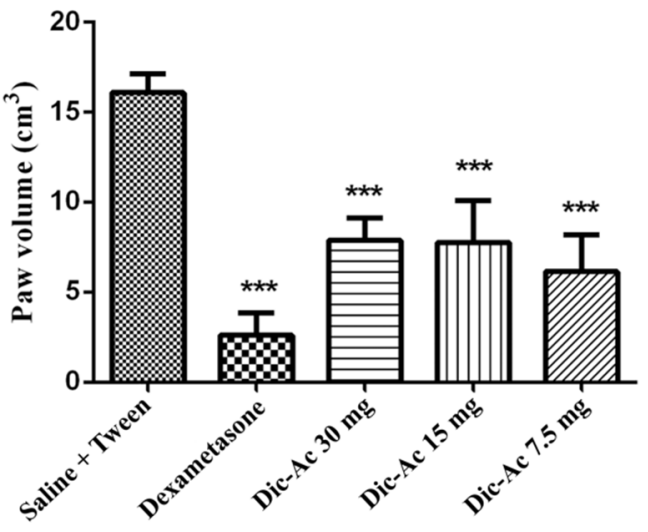

Treatment (after 4h)

(d)

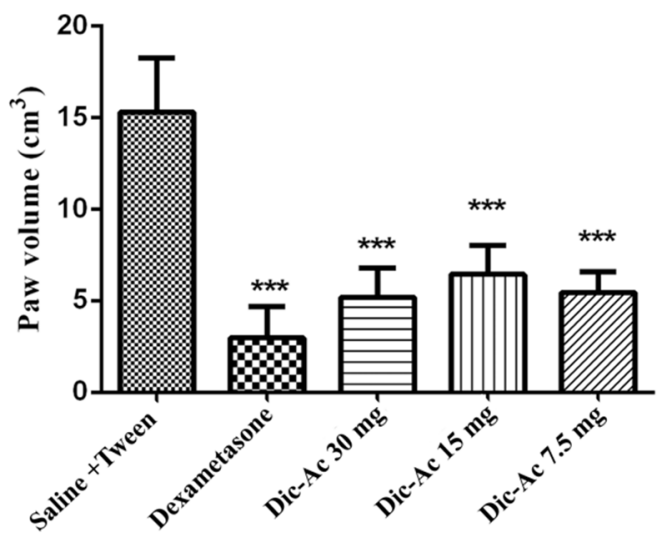

Treatment (after 5h)

(e)

Figure 2. Carrageenan-induced paw edema in mice from the control groups and treated with the Dic-Ac. Increased paw thickness after $1 \mathrm{~h}$ of evaluation (a), after $2 \mathrm{~h}$ of evaluation (b), after $3 \mathrm{~h}$ of evaluation (c), after $4 \mathrm{~h}$ of evaluation (d), after $5 \mathrm{~h}$ of evaluation (e). The results are expressed as mean \pm SEM of three repetitions. ${ }^{* * *} p<0.001$. Significant after two-way analysis of variance (ANOVA) followed by the Bonferroni test with a $95 \%$ confidence interval, when compared to the control group. 
Table 5. Inhibition of carrageenan-induced paw edema in mice from control groups and treated with the Dic-Ac.

\begin{tabular}{ccccccc}
\hline \multirow{2}{*}{ Group } & Oral Dose & \multicolumn{5}{c}{ Inhibition (\%) } \\
\cline { 3 - 7 } & & $\mathbf{1 ~ h}$ & $\mathbf{2 ~ h}$ & $\mathbf{3 ~ h}$ & $\mathbf{4} \mathbf{~ h}$ & $\mathbf{5 ~ h}$ \\
\hline Negative control & & & & & \\
Dexamethasone & $10 \mathrm{mg} \mathrm{kg}^{-1}$ & 70.2 & 81.8 & 88.5 & 83.6 & 79.5 \\
Dic-Ac & $30 \mathrm{mg} \mathrm{kg}^{-1}$ & 37.5 & 48.4 & 49.7 & 51.2 & 64.3 \\
Dic-Ac & $15 \mathrm{mg} \mathrm{kg}^{-1}$ & 27.6 & 42.8 & 52.4 & 51.6 & 57.3 \\
Dic-Ac & $7.5 \mathrm{mg} \mathrm{kg}^{-1}$ & 58.7 & 66.6 & 62.7 & 61.3 & 60.9 \\
\hline
\end{tabular}

Peters et al. (2003) [33] observed that the dichloromethane extract of Wilbrandia ebracteate (Curubitaceae) significantly inhibited inflammatory parameters in experimental models of in vivo and in vitro inflammation. An analysis of the chemical composition of the extract via HPLC indicated the presence of cucurbitacins in the extract.

\subsection{Anti-Tumor Activity}

The results were evaluated using the Dic-Ac. After checking for seven days and compared to the traditional treatment with Cisplatin antineoplastic agent, results showed a significantly reduction in tumor weights (Figure 3). The oral solutions of Dic-Ac presented anti-tumor activity by inhibition growth of TW\% $76.05 \%$ and $78.46 \%$ (Table 6 ), with total remission of the tumor on the seventh day of administration, which leads us to consider its importance ahead of usual therapies, which have side effects and are more costly.

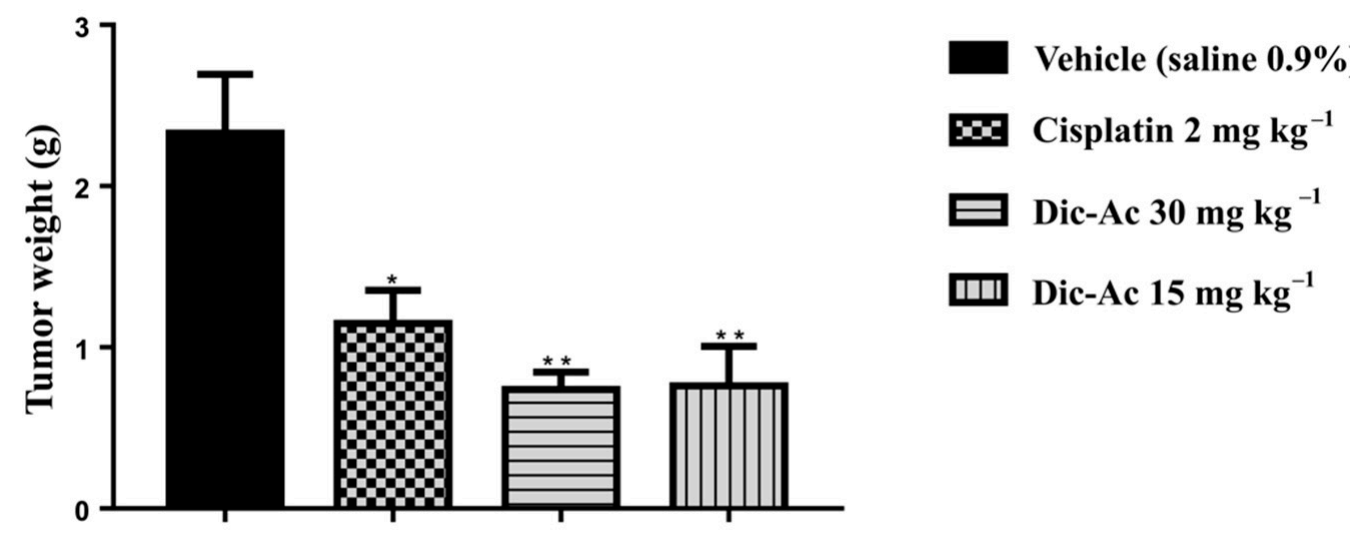

Treatment

Figure 3. The effect of Dic-Ac phase in the unit weight of the tumors. Mice were treated with DicAc (15 and $\left.30 \mathrm{mg} \mathrm{kg}^{-1}\right)$, vehicle ( $0.9 \%$ saline) and standard (cisplatin $2 \mathrm{mg} \mathrm{kg}^{-1}$ ) orally. Data are expressed as means $\pm \mathrm{SEM} ; n=5$ mice per group. ${ }^{*} p<0.05 ;{ }^{* *} p<0.01$. Significant after twoway analysis of variance (ANOVA), followed by the Tukey's multiple comparison test with $95 \%$ confidence interval.

Table 6. Inhibition of tumor growth in mice from control groups and treated with Dic-Ac $30 \mathrm{mg} \mathrm{kg}^{-1}$ and $15 \mathrm{mg} \mathrm{kg}^{-1}$.

\begin{tabular}{cccc}
\hline Group & Oral Dose & $\begin{array}{c}\text { Average } \\
\text { Weight (g) }\end{array}$ & $\begin{array}{c}\text { Inhibition } \\
\text { Index (TW\%) }\end{array}$ \\
\hline Negative control & & $2.25 \mathrm{~g}$ & $0.00 \%$ \\
Standard Cisplatin & $2.5 \mathrm{mg} \mathrm{kg}^{-1}$ & $1.15 \mathrm{~g}$ & $62.01 \%$ \\
Dic-Ac & $30 \mathrm{mg} \mathrm{kg}^{-1}$ & $0.78 \mathrm{~g}$ & $76.05 \%$ \\
Dic-Ac & $15 \mathrm{mg} \mathrm{kg}^{-1}$ & $0.70 \mathrm{~g}$ & $78.46 \%$ \\
\hline
\end{tabular}


During the tests, there was no death of any animals or behavioral changes such as arching gait, loss of muscle mass, stable dynamics, hair loss and loss of appetite.

The presence of cucurbitacins in the Dic-Ac suggests that these substances can play a fundamental role in reducing tumors. According to Liang and Dan (2019) [6] these compounds can exert antiproliferative effects against various cancers, acting by mechanisms such as inducing apoptosis, cell cycle arrest and autophagy. An in vivo study carried out with cucurbitacins E and I glucosides [34], also performed with Ehrlich's ascites carcinoma model, indicated that these compounds were able to decrease tumor size, prolong the survival time of the mice as the life expectancy, as well as normalize biochemical parameters of infected animals.

\section{Conclusions}

The results obtained showed that Apodanthera congestiflora is a relevant species in the search for pharmacologically active compounds. From the dichloromethane phase, 3 compounds were obtained. The spectroscopic analysis allowed the identification of them as being two triterpene saponins of cucurbitan nucleus belonging to the class of 29-norcucurbitacins and the identification as cayaponoside $C_{5 b}$ (Ac-1) and cabenoside $C$ (Ac-2), obtained for the first time in the genus Apodanthera, in addition to a new substance in the same class called fevicordin C2 glycoside (Ac-3).

The hemolysis test indicated low toxic potential, however, the acute toxicity test indicated that Dic-Ac has significant toxicity under the conditions evaluated. It was evidenced that the Dic-Ac has anti-inflammatory activity during the $5 \mathrm{~h}$ following the injury (paw edema) induced by carrageenan. The response observed was not dose-dependent and the dose of $7.5 \mathrm{mg} \mathrm{kg}^{-1}$ reached a $66.6 \%$ reduction in inflammation in the second hour of observation, this being a considerably low dose, considering that it is an organic phase and not of isolated substance.

Dic-Ac was able to significantly decrease volume of tumors induced by Ehrlich's carcinoma cells in mice. At a dose of $15 \mathrm{mg} \mathrm{kg}^{-1}$, the percentage of inhibition was $78.46 \%$, a result that indicates a strong potential of anti-tumor activity. These data reveal that $A$. congestiflora is a source of cucurbitacins and, therefore, it is possible to attribute it to a vast range of pharmacological potentialities.

Supplementary Materials: The following are available online at https: / www.mdpi.com/article / 10.3390/pharmaceutics13050743/s1, Figure S1: Infrared spectrum of the mixture of Ac-1, Ac-2 and Ac-3, Figure S2: ${ }^{1} \mathrm{H}$ NMR spectrum $\left(\delta\right.$, acetone- $\left.\mathrm{d}_{6}, 400 \mathrm{MHz}\right)$ of Ac-1, Ac-2 and Ac-3, Figure S3: ${ }^{1} \mathrm{H}$ NMR spectrum expansion ( $\delta$, acetone- $\mathrm{d}_{6}, 400 \mathrm{MHz}$ ) of Ac-1, Ac-2 and Ac-3, Figure S4: ${ }^{1} \mathrm{H}$ NMR spectrum expansion $\left(\delta\right.$, acetone- $\left.\mathrm{d}_{6}, 400 \mathrm{MHz}\right)$ of Ac- 1, Ac-2 and Ac-3, Figure S5: ${ }^{13} \mathrm{C}$ NMR spectrum $\left(\delta\right.$, acetone- $\left.\mathrm{d}_{6}, 100 \mathrm{MHz}\right)$ of Ac- 1, Ac-2 and Ac-3, Figure S6: ${ }^{13} \mathrm{C}$ NMR spectrum expansion $(\delta$, acetone$\left.\mathrm{d}_{6}, 100 \mathrm{MHz}\right)$ of Ac-1, Ac-2 and Ac-3; Figure S7. ${ }^{13} \mathrm{C}$ NMR spectrum expansion $\left(\delta\right.$, acetone- $\mathrm{d}_{6}, 100$ $\mathrm{MHz})$ of Ac-1, Ac-2 and Ac-3, Figure S8: ${ }^{13} \mathrm{C}$ NMR spectrum expansion $\left(\delta\right.$, acetone- $\left.\mathrm{d}_{6}, 100 \mathrm{MHz}\right)$ of Ac-1, Ac-2 and Ac-3, Figure S9: ${ }^{13} \mathrm{C}$ NMR spectrum expansion $\left(\delta\right.$, acetone- $\left.\mathrm{d}_{6}, 100 \mathrm{MHz}\right)$ of Ac-1, Ac-2 and Ac-3, Figure S10: ${ }^{13} \mathrm{C}$ NMR spectrum expansion $\left(\delta\right.$, acetone- $\left.\mathrm{d}_{6}, 100 \mathrm{MHz}\right)$ of Ac-1, Ac-2 and Ac-3, Figure S11: HSQC contour map- ${ }^{1} \mathrm{H} \mathrm{x}{ }^{13} \mathrm{C}$ of Ac-1, Ac-2 and Ac-3, Figure S12: HMBC contour map- $-{ }^{1} \mathrm{H} \mathrm{x}{ }^{13} \mathrm{C}$ of Ac-1, Ac-2 and Ac-3, Figure S13: Mass spectrum of Ac-1, Figure S14: Mass spectrum of Ac-2, Figure S15: Mass spectrum of Ac-3, Figure S16: ${ }^{1} \mathrm{H}$ NMR spectrum $(\delta$, acetoned6, $500 \mathrm{MHz})$ of dichloromethane phase, Figure S17: ${ }^{1} \mathrm{H}$ NMR spectrum expansion $(\delta$, acetone-d6, $500 \mathrm{MHz}$ ) of dichloromethane phase showing the region of terminal methyl at $\delta_{\mathrm{H}} 1.13$ analyzed by the TopicSpin Eretic-analysis 1, Figure S18: ${ }^{1} \mathrm{H}$ NMR spectrum expansion $(\delta$, acetone-d6, 500 $\mathrm{MHz}$ ) of dichloromethane phase showing the region of terminal methyl at $\delta_{\mathrm{H}} 1.13$ analyzed by the TopicSpin Eretic-analysis 2; Figure S19: ${ }^{1} \mathrm{H}$ NMR spectrum expansion ( $\delta$, acetone-d6, $\left.500 \mathrm{MHz}\right)$ of dichloromethane phase showing the region of terminal methyl at $\delta_{\mathrm{H}} 1.13$ analyzed by the TopicSpin Eretic-analysis 3. 
Author Contributions: Coordination and supervision of research: H.S.A.; treatment of plant material and preparation of extracts: G.F.G.S.; phytochemical screening: R.P.L.; in vitro toxicity: G.D.O. and R.P.L.; chromatographic isolation: G.F.G.S., G.D.O. and R.P.L.; structural identification of chemical compounds: H.S.A. and G.F.G.S.; in vivo pharmacological assays and statistical analysis: H.N.P., J.A.B.D. and I.A.S.; writing of the manuscript: G.F.G.S.; revision of the manuscript: H.S.A. All authors have read and agreed to the published version of the manuscript.

Funding: This study was financed in part by the State University of Paraíba grant $001 / 2021$. This research was carried out thanks to the support given by Coordination for the Improvement of Higher Education Personnel (CAPES), Ministry of Education and National Council for Scientific and Technological Development (CNPq), PROPESQ-2017/UEPB.

Institutional Review Board Statement: All experiments were carried out in accordance with the standards established by the Brazilian Society of Science in Laboratory Animal (SBCAL) and with the standards established by the National Institute of Health Guide for Care and Use of Laboratory Animals. The Ethics Committee on Use in Animals (CEUA-UEPB) approved this study, which was registered as process No 002/2020 on 14 October 2020.

Informed Consent Statement: Not applicable.

Data Availability Statement: Data available on request.

Acknowledgments: Pharmaceuticals and Medicines Research Institute-Federal University of Paraíba (IPeFarM/UFPB); Pharmaceutical Product Development and Characterization Laboratory (LDCPF/UEPB); Laboratory for Testing and Development of Medicines (LABDEM/UEPB); Center for Research and Extension in Food (NUPEA/UEPB).

Conflicts of Interest: The authors declare no conflict of interest.

\section{References}

1. Xu, Z.; Chang, L. Cucurbitaceae. In Identification and Control of Common Weeds; Springer: Singapore, 2017; pp. 417-432.

2. Gomes-Klein, V.L.; Hall, C.F.; Gil, A.S.B. Flora das cangas da Serra dos Carajás, Pará, Brasil: Cucurbitaceae. Rodriguésia 2016, 67, 1319-1327. [CrossRef]

3. Silva, G.T.M.D.A.; Ribeiro, R.M.P.; Barros Júnior, A.P.; Silveira, L.M.; Ribeiro Júnior, P.M.; Albuquerque, N.R.C. Characterization of cucurbit production systems and disease prevalence in municipalities in Pernambuco. Rev. Caatinga 2016, 29, 774-779. [CrossRef]

4. Méndez-Cuesta, C.A.; Campos, A.L.E.; Sánchez, D.S.; González, C.P.; Gutiérrez, S.P. Cytotoxic and antitumoral activities of compounds isolated from Cucurbitaceae plants. In Pharmacognosy-Medicinal Plants; IntechOpen: London, UK, 2018; pp. 1-18.

5. Morales-vela, K.; Pérez-Sánchez, F.C.; Padrón, J.M.; Márquez-Fernándes, O. Antiproliferative activity of Cucurbitaceae species extracts from southeast of Mexico. Preprints 2019, 100, 1-12. [CrossRef]

6. Liang, J.; Dan, C. Advances in research on the anticancer mechanism of the natural compound cucurbitacin from Cucurbitaceae plants: A review. Tradit. Med. Res. 2019, 4, 68-81. [CrossRef]

7. Ali, M.S.; Mukherjee, S.; Makar, S.; Pal, G. Cucurbitacins a Vibrant Triterpenoid: A Review on its Anticancer Property. PharmaTutor 2019, 7, 43. [CrossRef]

8. Ríos, J.L.; Escandell, J.M.; Recio, M.C. New insights into the bioactivity of cucurbitacins. Stud. Nat. Prod. Chem. 2005, 32, 429-469. [CrossRef]

9. Kaushik, U.; Aeri, V.; Mir, S.R. Cucurbitacins-An insight into medicinal leads from nature. Pharmacogn. Rev. 2015, 9, 12-18. [CrossRef]

10. Madaleno, I.M. Plantas da medicina popular de São Luís, Brasil. Bol. Mus. Para. Emílio Goeldi. Ciênc. Hum. 2011, 6, 273-286. [CrossRef]

11. Roque, A.A.; Loiola, M.I.B. Potencial de uso dos recursos vegetais em uma comunidade rural no semiárido potiguar. Rev. Caatinga 2013, 26, 88-98.

12. Silva, C.G.; Marinho, M.G.V.; Lucena, M.F.A.; Costa, J.G.M. Levantamento etnobotânico de plantas medicinais em área de Caatinga na comunidade do ítio Nazaré, município de Milagres, Ceará, Brasil. Rev. Bras. Plantas Med. 2015, 17, 133-142. [CrossRef]

13. Pereira, H.N.; Guimarães, G.P.; de Melo Trovão, D.M.; da Silva Alves, H. Physicochemical characterization of the vegetal drug and nebulized extract of the roots from Apodanthera congestiflora Cogn. (Cucurbitaceae): An efficient experience in quality control of plant raw materials. J. Therm. Anal. Calorim. 2019, 137, 361-368. [CrossRef]

14. Videres, L.C.C.A. Apodanthera Congestiflora e Myracrodruon Urundeuva: Investigação das Propriedades Biológicas em Preparações Brutas e Produtos Isolados. Ph.D. Thesis, Universidade Federal de Pernambuco, Recife, Brazil, 2017.

15. Pinto, D.S.; Duarte, F.M.; Costa, J.I.V.; Almeida Filho, G.G.; Alves, H.S.; Chaves, M.C.O.; Pessoa, H.L.F.P. Antibacterial and Hemolytic Activities from Piper montealegreanum Yuncker (Piperaceae). Anti-Infect. Agents 2012, 10, 1-5. [CrossRef] 
16. OECD Guideline for Testing of Chemicals: Acute Oral Toxicity: Acute Toxic Class Method. [S.1.]. 2001. (OECD/OCDE, 423). Available online: https:/ / www.oecd-ilibrary.org/environment/test-no-423-acute-oral-toxicity-acute-toxic-class-method_9789 264071001-en (accessed on 17 December 2001).

17. Stock, C.C.; Clark, D.A.; Philips, F.S.; Barclay, R.K.; Myron, S.A. Sarcoma 180 screening data. Cancer Res. 1960, $20,193-381$. [PubMed]

18. Machon, Z.; Kuczynski, L.; Gieldamowski, J.; Wieczorek, Z.; Zimecki, M.; Blaszczyk, B.; Mordarski, M.; Wieczorek, J.; FiszerMaliszewska, L. Chemical and biological properties of 2-pyridyl-benzyl-carbinol. Arch. Immunol. Ther. Exp. 1981, $29,217-233$.

19. Pavia, D.L.; Lampman, G.M.; Kriz, G.S.; Vyvyan, J.R. Introduction to Spectroscopy, 4th ed.; Brooks/Cole: Belmont, CA, USA, 2012.

20. Achenbach, H.; Waibel, R.; Hefter-Bübl, U.; Constenla, M.A. Constituents of Fevillea cordifolia: New Norcucurbitacin and Cucurbitacin Glycosides. J. Nat. Prod. 1993, 388, 1506-1519. [CrossRef]

21. Nakano, K.; Kanai, Y.; Murakami, K.; Takaishi, Y.; Tomimatsu, T. Nor-cucurbitacin glucosides from Caputo nigri. Phytochemistry 1994, 37, 817-820. [CrossRef]

22. Valente, L.M.M. Cucurbitacinas e suas principais características estruturais. Quim. Nova 2004, 27, 944-948. [CrossRef]

23. Himeno, E.; Nagao, T.; Honda, J.; Okabe, H.; Irino, N.; Nakasumi, T. Studies on the Constituents of the Root of Cayaponia tayuya (VELL.) COGN. III. Structures of Cayaponosides, 29-Nor-1,2,3,4,5,10-hexadehydrocucurbit-6-ene Glucosides. Chem. Pharm. Bull. 1994, 42, 2370-2372. [CrossRef]

24. Achenbach, H.; Hefter-Bübl, U.; Constenla, M.A. Fevicordin A and fevicordin A glucoside, novel norcucurbitacins from Fevillea cordifolia. J. Chem. Soc. Chem. Commun. 1987, 441, 441-442. [CrossRef]

25. Chen, J.C.; Chiu, M.H.; Nie, R.L.; Cordel, G.A.; Qiuz, S.X. Cucurbitacins and cucurbitane glycosides: Structures and biological activities. Nat. Prod. Rep. 2005, 22, 386-399. [CrossRef]

26. Silvestre, G.F.G. Estudo Fitoquímico e Farmacológico de Apodanthera congestiflora Cogn.: Uma Cucurbitaceae da Caatinga Brasileira. Master's Thesis, Universidade Estadual da Paraíba, Campina Grande, Brazil, 2020.

27. Tavares, R.L.; De Vasconcelos, M.H.A.; da Veiga Dutra, M.L.; D'Oliveira, A.B.; Lima, M.D.S.; da Silva Stiebbe Salvadori, M.G.; de Alencar Pereira, R.; Alves, A.F.; do Nascimento, Y.M.; Tavares, J.F.; et al. Mucuna pruriens Administration Minimizes Neuroinflammation and Shows Anxiolytic, Antidepressant and Slimming Effects in Obese Rats. Molecules 2020, $25,5559$. [CrossRef] [PubMed]

28. Simões, C.M.O.; Schenkel, E.P.; Gosman, G.; Mello, J.C.P.; Mentz, L.A.; Petrovick, P.R. Farmacognosia: Da Planta ao Medicamento; Editora da UFSC: Florianópolis, Brazil, 2007.

29. Pereira, H.N. Estudo Fitoquímico e Atividade Biológica das Raízes de Apodanthera congestiflora Cogn. (Cucurbitaceae). Master's Thesis, Universidade Estadual da Paraíba, Campina Grande, Brazil, 2017.

30. Oga, S.; Camargo, M.M.D.A.; Batistuzzo, J.A.D.O. Fundamentos da Toxicologia, 3rd ed.; Atheneu: São Paulo, Brazil, 2008.

31. Guyton, A.C.; Hall, J.E. Tratado de Fisiologia Médica, 13th ed.; Elsevier: Rio de Janeiro, Brazil, 2017.

32. Schons, S.V.; Kommers, G.D.; Pereira, G.M.; Raffi, M.B.; Schild, A.L. Estudo histológico, imuno-histoquímico e ultra-estrutural das lesões induzidas experimentalmente por Ramaria flavo-brunnescens (Clavariaceae) em bovinos. Pesq. Vet. Bras. 2007, 27, 269-276. [CrossRef]

33. Peters, R.R.; Krepsky, P.B.; Siqueira-Junior, J.M.; Rocha, J.C.S.; Bezerra, M.M.; Ribeiro, R.A.; Brum-Fernandes, A.J.; Farias, M.R.; Rocha, F.A.C.; Ribeiro-Do-Valle, R.M. Nitric oxide and cyclooxygenase may participate in the analgesic and anti-inflammatory effect of the cucurbitacins fraction from Wilbrandia ebracteata. Life Sci. 2003, 73, 2185-2197. [CrossRef]

34. Ayyad, S.-E.N.; Abdel-Lateff, A.; Alarif, W.M.; Patacchioli, F.R.; Badria, F.A.; Ezmirly, S.T. In vitro and in vivo study of cucurbitacins-type triterpene glucoside from Citrullus colocynthis growing in Saudi Arabia against hepatocellular carcinoma. Environ. Toxicol. Pharmacol. 2012, 33, 245-251. [CrossRef] [PubMed] 